\title{
The Role of Party Construction in the Cultivation of Talents in Colleges and Universities
}

\author{
Lin Zhu \\ School of Mathematical Sciences, Shanghai Jiaotong University, Shanghai, 200240, China
}

Keywords: Party construction, Colleges and universities, Talents training.

\begin{abstract}
The essence of higher education is to cultivate talents. With the comprehensive development of higher education and the expansion of college enrollment, new problems related to the students' interests appear constantly. It urges to strengthen the ideological and political education of students in colleges and universities. The party branch is one of the important backbone for colleges and universities to carry out the ideological and political education. The colleges and universities must do a good job in party construction, which requires us to continue to explore the method and path on party construction. The grassroots party construction in colleges and universities can meet only the main requirements of the university educatio, and serve for general situation, so as to provide comprehensive and efficient service of talents training for colleges and universities. The article analyzes the relation between the university party construction and talent training, and generally explores the current problems existed in the party construction in colleges and universities. Based on this, it puts forward the concrete paths that the party construction plays an important role in the talent cultivation in colleges and universities
\end{abstract}

\section{Introduction}

With the fierce competition on ideology in today's society, colleges and universities is not only a positon of ideological concentration and confrontation, and a forefront of various ideological form development, but also is an important place for talent training. In the face of the impact of the western ideological consciousness, The colleges and universities only grasp the leadership and voice of ideology firmly, and lead the masses of teachers and students to establish a firm socialist ideal and faith, as well as consolidate the party's leadership in the construction of talent training, together with the improvement of the identity of teachers and students on the party and socialist theory, so that more and more successor of socialism can be cultivated.

\section{The relationship between the party construction and the talents training}

The first task of colleges and universities is to cultivate talents. The cultivation of talents in colleges and universities is not only related to the basic interests and long-term interests of the party and the country, but also to the future of the nation and society. The colleges and universities are the main positions of talent training, and the leadership of the party is a key factorto develop the Talents cultivationin colleges and universities.The colleges and universities must do well in party construction, so that more excellent talents can be cultivated.

\subsection{The party construction in colleges and universities determines the direction of talent cultivation in colleges and universities}

Party construction in colleges and universities directly affects whether the leadership of the party is at the core place in the college education, and the implementation of the party's education guideline, education policy in the talent cultivation in colleges and universities, as well as the school-running direction in colleges and universities. At present, the party construction in colleges mainly contains two main parts: teacher party construction and student party construction. The party construction of teacher plays an extremely important role in the cultivation of talents in colleges and universities. 
Teachers are the guiders for young students' growth. What kinds of talents will be cultivated is depended greatly by teachers, so teachers' ideological and political quality and moral sentiment have a strong influence on students. Teachers are the main force of school reform, scientific research innovation and development. if teachers' party construction is not very well, the efficiency and quality of talents training in colleges and universities will become worse, whcih will constrain students' party construction as well.

\subsection{The effect of talent training in colleges and universities directly reflects the level of party construction in colleges and universities}

Talent training is one of the mission and the basic task for colleges and universities. Party committees of colleges and universities bear the resonsibiities of the leadership of education development, the maintenance of stable and harmonious campus in colleges and universities,as well as the grasp of school-running orientation in colleges and universities. Also, the effect of talent training directly reflects to the level of the party construction in colleges and universities. Party organizations in colleges and universities is the core strength for the constant development of colleges and universities. Only in the way of constantly strengthening the party construction can unify the value concept of traning people, integrating and optimizing talent training resources, as well as deepening the function of education in colleges. Only in the way of constantly strengthening the development of party construction can we correctly master the rules of talent training, and cultivate students' all-round development.

\subsection{It is the requirement of the times and social development to do the party construction well and let it play a role in the Talents cultivationin colleges and universities.}

The image, prestige, creativity, cohesion and fighting force of the CPC are related to the fate of the party, the country, the nation and the people. In the new era, the communist party of China faces to all kinds of serious tests, such as government ruling, market economy and so on. All these tests are at long term and are very complex.

With the enhancement of the comprehensive strength of China's society, the prevention consiousness of western countries to our country becomes more and more serious, and western countries often use all kinds of sensitive topics to abuse the political system and development path of our country. Colleges and universities is a place to cultivate talents and to create and gather advanced thoughts. Under this kind of background, it is very important to develop party construction well in colleges and universities, and to play the role in the development direction in colleges and universities, and to promote talents traning. The reform and opening up policy in China improves comprehensive national strength, but at the same time, it also intensifies the conflicts of interest. the mainstream consciousness and ideology has also been impacted a lot. It is hard to know whether the large amount of network information is true or not, and the ideological field of the youth is increasingly blurred. The management educational thoughts of some colleges and universities are too utilitarian, and the strength of party construction team is weak. Teachers' ideological qualities are uneven, which weakens the marxist ideology in the process of talents traning.

In the process of talent cultivation in colleges and universities, the core position strength of party construction on the the talent cultivation must be improved, and the fighting fort effect of the party organization must be taken. Lead the masses of teachers and students to be of socialist ideal faith firmly, and strengthen the theoretical identity, emotional identity and political identity. Carry out the educational guideline of strengthening moral educaiton and cultivate people, and train more qualified successors for the socialist construction.

\section{Promote the path of the party construction to play a role in the talents cultivation in colleges and universities}

\subsection{Strengthen teacher ethics and enhance the persuasive power of party construction}

In order to provide better service for talents cultivation, party organizations in collegies and 
universities must actively build the talents cultivation systemn based on taking party members and excellent teachers as examples, and improve the standardized leading role of teachers among party members in the teaching practice work, as well as enhance the exemplary roles of students among party member. The party committee of colleges and universities can strengthen teachers' morality and enhance the persuasion of party construction in colleges and universities.

Firstly,concentrate the cohesion of all staff in colleges and universities, and promote the reform of talents cultivation mode together. Party organizations in colleges and universities can supervise the party branch according to the disciplines and professionals, and select outstanding teachers who are responsible and have the consciousness of service, as well as the dedication and high professional level as the discipline or professional leaders. Teachers in party members can affect students by their own charms, and cultivate and promote students' sense of identity. It also facilitate to penetrate the party branch work into the party construction for professional teachers. Teachers in all kinds of diciplines combine with their characteristics of subjects, and integrate the party knowledge into the whole process of talents cultivation. In addition, teachers can organize team members to build science and technology innovation team, and lead the party activists and students actively to participate in project construction. Through the construction of the extracurricular platform of "school platforms, teachers' guidance, and students' performanc", teahcers in the party can fully mobilize the enthusiasm and initiative of students to participate in scientific and technological innovation, and can cultivate and improve the students' ability of practice and innovation

Secondly, Cultivate and enhance the ability of students to serve for the society by conducting voluntary activities from different majors. Based on the social requirements and serving for the society, when developing the majors, colleges and universities should integrate the party construction and professional learning through the way of conducting the volunteer activities by majors. For example, the party organization can let the students party members of management social work department and activists of party application do volunteering jobs in welfare house and streets. Under the infuence of teachers and students, other students in the management social work department will take part in the activities actively, and the consiousness of serving for the society in students'minds will be enhanced and improved.

Thirdly, Set up the exemplary and vanguard models, and play the model leading role of students units. The construction of study style is the eternal theme of the development of colleges and universities, and is also a key segment in the cultivation of talents in colleges and universities. Integrate the construction of study style into the party construction, and establish a learning model to play the role of model and example in the construction of study style. From all segments of the construction of study style, evaluate comprehensively on students' learning purposes, learning effects, and other contents, and add students' performance into the party evaluation .

\subsection{Expand education channels, and integrate and optimize education resources, as well as improve the influence of party members' work}

It is not enough to cultivate high quality application-oriented talents just from colleges and universities. It also requires the efforts of schools, the government, the society and the family. School party committee should mobilize all aspects of resources, and get more supports and education resources through the opening ceremony, university-enterprise cooperation exchange, practice training base the lecture hall and so on. Construct network platforms which consists of the students' parents, alumni, experts and scholars and people in the society, and build a new force point of talents cultivation in colleges and universities.

First of all, the party organization of colleges and universities needs to continuously explore and develop channels of education. Through the combination of theoretical education of the party committees in colleges and universities and soical parctical education, construct the ideological and political education system, which is of unified work objectives, educational contents, division of responsibilities and mutual coordination. Strengthen ideological and political education of college students, and enhance the ideological and political quality of college students. Party committees of colleges and universities can hold face-to-face communication of party representatives, experts and 
scholars with students, and hold the campus reports meeting related to the party education, as well as other party construction educational theme activities that students are fond of.These activities can make the socialist ideal faith education penetrate to the whole talent cultivation activity, which can improve students' consciousness of ideological and political quality, service, and dedication to the society.

The party committees of colleges and universities should strengthen the connection and communication among students'parents, experts, the alumni, and provide a convenient platform for students'parents, experts, the alumni to participate in the talent cultivation. Party organizations in colleges and universities can hold fellowship meeting, alumni associations among colleges, and can also invite parents and alumni to military training of freshmen, the opening ceremony, graduation ceremony, and other educational activities.

The party committee of colleges and universities should constantly promote the cooperation between schools and enterprises, and establish a good and deep cooperative relationship with the party organization. The party committee of colleges and universities can cooperate with the enterprise party organization, and holds the education activities that are of distinct themes, and are in various forms together. And provide the knowledge education ,the party job training and other services for instructors, students, staff of enterprise party construction. The cooperation between the party committee organization in colleges and universities and the enterprise party organizationcan contributes to the construction of the school-enterprise cooperative education mode, and the enterprises' acceptance of outstanding party member graduates can help to carry out the professional practice teaching with the alternation of industry and technology.

\subsection{Implement education management and improve the cohesion of party construction constantly}

Establish the party branch in class, and play the fortress function to the class party branch fully. Class plays an important role in talent cultivation. Party organizations and teachers in colleges and universities must actively create good classroom learning atmosphere, and strengthen the ideological and political educationtraning of activists of party aplication in students party member. Play the fortress function to the class party branch fully. The party organization of colleges and universities can set up a party branch in the conditions of the mature senior class, and lead to common progress of the class. And in the construction of class, form a trinity of education management mode among party branch committee, league branch and class, and carry out the education management to create a good study style. Party committee organization in colleges and universities can implement the education management mechanism of party members' leading of the class, and fully has a leading role of students party members, the activists in the study style construction and daily management. Lead the students to grow, and play a main role in the students' self-education, self-management and self-service

Party organizations in colleges and universities must establish a healthy network ideological and political education environment for students, and provide high quality network service for talents in colleges and universities. According to the new network public opinion development trend, an combined with the actual development situation, create public opinion weekly, and understand students'ideas. Have the equal dialogue with students, and reduce psychological distance among teachers, students, party members and the masses. Pevent the market contradiction, and realize the harmonious and stable campus. Provide high quality and comprehensive service for campus to cultivate talents with firm ideas and faith, and solid professions and techniques, as well as high comprehensive qualities.

\subsection{Build an integrated platform for the production, education and scientific research, and cohere the party's strength}

Cooperative education of the production, education and scientific research is a new type of talents cultivation mode which integrates the production, education and scientific research together, and it is the important path to improve the level of talents cultivation, students' quality education and the commercialization of scientific research achievements in colleges and universities. The party branch 
plays a political core role in the development of the discipline construction of talents construction, and actively participates in every segments of teaching, scientific research and management. In the cultivation of talents, it is important to combine the characteristics of interdisciplinary disciplines, formulate training plans according to different professional characteristics.Also, it is important to set up the education curriculum of party construction and revise the content of party construction teaching. Based on the combination of party construction and disciplinary education, the party committee should pay attention to the integration and optimization of various teaching resources, and play the exemplary leading role in party members.

Cooperative education of the production, education and scientific research can meet the demands of current society, economy, science and technology for talents. It is complied to the educational development rules. It is an education mode for colleges and universities to implement the education guideline and education policy of party, and satisfy the developments demands of social economy, and cultivate applied professional talents with creative spirit and practice ability of high quality. Cooperative education of the production, education and scientific research requires that the discipline construction of the research institute must be focused on the goal of the talent cultivation, and the scientific construction will directly serve for the cultivation of college applied talents. There is no construction of cooperative education of the production, education and scientific research that is only for discipline construction. Secondly, use discipline construction to drive development. To achieve this education pattern, the party needs to improve the cohesion constantly, and promote the school talents cultivation and discipline construction.

\section{Conclusion}

If Party construction in colleges and universities wants to play the leading and promoting roles in talents cultivation, it must be closely focused on educational goal of strengthening moral education and cultivating people. Through the people-oriented construction policy, and taking the education concept of "morality first, ability important, all-round development" of as the instruction, the socialist core values will be integrated into the entire process of talents cultivation, which will cultivate more qualified successors for the healthy development of socialism with Chinese characteristics.

\section{References}

[1] Zhang Ke, Zeng Qingiang's strategic thinking on the construction of college students' party construction in the new era, Journal of economic research, 22.

[2] CPC Shenyang Agricultural University Committeegrasps the leadership of ideological work firmly, and actively created a good environment for the comprehensive reform of universities, Liaoning Daily, 2015, 04, 10.

[3] Ji Yihong, JanFunPing, the reform and innovation of college students ' Party construction under the visoin of Yanfu ping. Hefei Journal: Social Science Edition, 2014, 28.

[4] He HuiXing, Sun SongLun's discussion on the modernizeation of university governance system and governance capacity higher agricultural education, 2014, 9.

[5] General Office of the Ministry of Education. The Secretary and minister of the Ministry of Education's, Yuan Guiren, summary speech in the 23rd National Conference on the construction of CPC, 2015,04.

[6] CPC Shenyang Agricultural University Committee firmly grasp the leadership of ideological work, and actively creates a good environment for the comprehensive reform of universities, Liaoning daily, 2015, 4,110 (07) 